\title{
Constructive Supervisory Confrontation: What Employees Want
}

\author{
Tab W. Cooper, M.B.A., Sam Houston State University, USA
}

Lucia Stretcher Sigmar, Ph.D., Sam Houston State University, USA

\begin{abstract}
Confronting others with constructive criticism and feedback to hold them accountable for their actions and behavior is an important leadership skill in managing people. While the majority of literature generally supports the need for constructive supervisory confrontation in the workplace, few studies have attempted to quantify the issue of supervisory confrontation from the employees' perspective. Using data from a 2010 survey of 69 mid-and lower-level employees, this study examines employee perception of two primary forms of supervisory confrontation: supportive and corrective feedback. Our research quantifies six, statistically significant areas of confrontational behavior that were valued by employees and ranks their relative importance in the workplace. Our hypothesis is that positive and supportive feedback is valued more highly by employees, and leaders who are socially and emotionally skilled will have a greater impact on employee performance. An understanding of employee perception and valuation of confrontational behavior can improve supervisory leadership, and can also promote employee job satisfaction, motivate employees, eliminate the need for constant supervision, and influence the quality of and improve workplace relationships.
\end{abstract}

Keywords: Constructive Supervisory Confrontation; Supportive and Corrective Feedback

\section{INTRODUCTION}

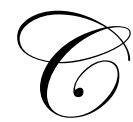

onfrontation has been perceived as the weakest link in leadership within an organizational context (Hoover \& DiSilvestro, 2005). Supervisors, who often lack proficiency with specific interpersonal communication skills needed to successfully and constructively confront others in a civil and productive manner, misunderstand confrontation, fail to provide timely feedback, and in some cases, avoid confrontation altogether. When supervisors do confront employees, the confrontation is usually an expression of frustration, not of skilled leadership (Hoover \& DiSilvestro, 2005).

The unintended consequences of direct (aggressive) supervisory confrontation (either verbally or nonverbally) have been well documented (Hatfield, Cacioppo, \& Rapson, 1994; Lerner \& Tiedens, 2006; Wubben, Cremer \& Kijk, 2009; Canary, Spitzberg, \& Semic, 1998; Sampson, 2003). Aside from increasing the risk of civil liability on the supervisor's part, the employee may perceive the supervisor's behavior as disrespectful, offensive, or threatening, and may feel a range of defensive and negative emotions which escalate conflict and prompt retaliation (Hatfield, Cacioppo, \& Rapson, 1994; Lerner \& Tiedens, 2006; Wubben, Cremer, \& Kijk, 2009; Canary, Spitzberg, \& Semic, 1998; Sampson, 2003). It is no wonder that many supervisors try to avoid confrontation altogether out of fear of damaging relationships or from a lack of confidence in managing a situation.

Avoiding confrontation, however, is often as damaging as confronting an employee directly. Supervisors who withhold feedback (either verbally or non-verbally) can create severe emotional distress in employees that is often greater than the pain received from negative feedback (Williams, 2005). It can also lead to employee alienation and neglect (Kanungo, 1992) which often results in dramatic decreases in employee morale, productivity, and performance. This neglect can further lead to stress, anxiety, depression, and other forms of psychosomatic illness (Sashkin, 1984; Kornhauser, 1965). This type of alienation and neglect is a form of psychological punishment which undermines trust - a necessary component of any working relationship. 
Employees invest a significant amount of time and effort in the workplace, and in addition to fulfilling the obvious financial needs, organizations are expected to fulfill at least some of the employee's emotional, social and psychological needs. Kanungo (1992) suggests that "the individual has a natural inclination to grow from a state of psychological immaturity and infantile dependence to a state of maturity and independence" (p. 415) which, we would argue, also includes professional growth for employee - and for employer. Organizations invest a significant amount of time, money, and effort in developing their employees and expect commitment to the organization and delivery of its strategic goals and objectives. Both the organization and the employee benefit when supervisors develop effective confrontation skills to achieve performance and strategic goals in the workplace.

Constructive confrontation is used variously in workplace scenarios as retribution or catharsis, to influence outcomes, to maintain relationship and stature, or to enhance personal understanding--including the desire to be argumentatively complete (Newell \& Stutman, 1989/90). In addition, constructive confrontation contributes greatly to organizational stability and direction, inspires respect and confidence in a supervisor's employees or between coworkers, and promotes employee confidence and capability. Workers are empowered (not diminished) by the confrontation (Bandura, 1986). Further, they recognize that confrontation is in their own best interest and in the interest of the organization as a whole. Confronting others with constructive criticism and feedback in order to hold them respectfully accountable for their actions and behavior is an important leadership skill in managing people.

\section{PURPOSE}

Although the majority of literature generally supports the need for effective confrontation in the workplace (Blanchard, 1982; Hoover \& DiSilvestro, 2005; Karp, 1987; Cormier and Hackney, 2005; Kanungo, 1992; Seeman, 1959; Tucker, 1993; Velasquez, 1982; Williams, 2005; Wolf, 1991) and details which skill sets to develop (Blakeman, Keeling, Pierce \& Carkhuff, 1977; Carkhuff, 1983; Karp, 1987; Sampson, 2003; Williams, 2005), few studies have attempted to quantify the issue of supervisory confrontation from the employees' perspective. This study examines employee perception of confrontation in the workplace in two primary forms of supervisory confrontation: supportive feedback and corrective feedback. By identifying the supervisory qualities that employees value, rather than those qualities deemed important by theoreticians or supervisors themselves, this study attempts to improve the overall quality of supervisory interaction with human resources. We sought answers to the following questions:

\section{RESEARCH QUESTIONS}

1. What kinds of supportive and corrective behaviors are valued by employees?

2. What is their relative importance to employees?

\section{METHODOLOGY}

This study was conducted at an AACSB-accredited university during the fall of 2010. Students enrolled in nine sections of a 300-level business communication course were encouraged to follow a Facebook hyperlink to Surveymonkey.com to complete a survey dealing with their experience with supervisory confrontation. They were also encouraged to share the survey link with friends and family who had experienced supervisory confrontation. In total, sixty-nine individuals participated in the study. Seventy percent of the respondents were female; thirty percent of the respondents were male. During their supervisory confrontation, approximately half $(51 \%)$ of participants were college age (18-22), 39\% were age 23 or older, and 10\% were 16-17 years of age. At the time of their confrontation, half $(50.7 \%)$ of participants had worked with their supervisors for 1-3 years, $29 \%$ had worked with their supervisors for under a year, and $14 \%$ had worked with their supervisors for 3 or more years. Almost half (49.2\%) of participants worked over 30 hours a week; $40.5 \%$ worked $16-30$ hours per week, and 10\% worked less than fifteen hours a week. Over half $(53.6 \%)$ of all participants surveyed were employed in retail or food service industries.

The 36- item survey (see Appendix A) used an 8-point Likert scale to measure two primary dimensions of the supervisor-employee relationship from the employee's perspective: 1) employee perception of supervisor's behavior, and 2) an employee's reaction to the supervisor's behavior. Pearson's Correlation Coefficient was used to analyze the data. 


\section{DISCUSSION OF FINDINGS}

Helping employees maintain or enhance effectiveness and appropriate behavior should be the purpose of all feedback, but "[o]ne of the most damaging and erroneous assumptions that many supervisors make is that good performance and appropriate behavior are to be expected from the employee and that the only time feedback is needed is when the employee does something wrong" (Karp, 1987, p. 237). Researchers, however, have long considered positive, supportive feedback more effective than negative feedback (Karp, 1987; Cormier \& Hackney, 2005), and this study's data supports that assumption (see Table 1). Isolating only the data that ranked statistically significant in our survey findings (.330 and higher), we determined specific areas of supervisory performance (supportive behaviors and corrective feedback) which employees value the most. At its highest level of statistical significance, our data indicate that employees highly value employer feedback when it reinforces desirable and effective behavior (.833). These statistics, however, drop dramatically when employers use negative supervisory confrontation feedback techniques such as scolding or talking down to the employee (.-627) or worse, focus exclusively on what is wrong with the employee's performance (-.700).

Table 1: Employee Perception of Supervisory Behavior

\begin{tabular}{|c|c|c|}
\hline & $\begin{array}{l}\text { Employees who } \\
\text { received positive } \\
\text { feedback. }\end{array}$ & $\begin{array}{l}\text { Employees who } \\
\text { received negative } \\
\text { feedback. }\end{array}$ \\
\hline $\begin{array}{l}\text { Positive Feedback } \\
\text { My supervisor encourages me when I feel like I am doing a very good job }\end{array}$ & .833 & -.700 \\
\hline $\begin{array}{l}\text { My supervisor frequently gives me positive feedback by telling me how I am } \\
\text { performing my job correctly }\end{array}$ & & -.572 \\
\hline $\begin{array}{l}\text { Empathy } \\
\text { My supervisor is understanding }\end{array}$ & .753 & -.709 \\
\hline My supervisor is patient with employees & .721 & -.606 \\
\hline My supervisor is frequently uncaring, unconcerned, aloof, or indifferent & -.672 & .678 \\
\hline I feel that my supervisor ignores me & -.577 & .634 \\
\hline $\begin{array}{l}\text { Respect } \\
\text { My supervisor demonstrates respect toward employees most of the time }\end{array}$ & 655 & -.663 \\
\hline My supervisor is known to help employees with some basic tasks & .587 & -.481 \\
\hline $\begin{array}{l}\text { My supervisor is quick to point out what's wrong, but not so quick to point } \\
\text { out what's right with my performance }\end{array}$ & -.572 & \\
\hline My supervisor frequently threatens to fire employees to motivate them & -.476 & .519 \\
\hline $\begin{array}{l}\text { My supervisor frequently scolds or talks down to me while providing me } \\
\text { feedback about my work performance }\end{array}$ & -.469 & 606 \\
\hline $\begin{array}{l}\text { I dislike when my supervisor vents his/her frustration when confronting me } \\
\text { about an issue at work }\end{array}$ & -.447 & .476 \\
\hline My supervisor has been known to be verbally abusive to employees & & .568 \\
\hline When my supervisor corrects me, I feel defensive or embarrassed & & .483 \\
\hline My supervisor cares about his/her employees & .762 & -.576 \\
\hline $\begin{array}{l}\text { Participatory } \\
\text { When there is an issue involving me, my supervisor lets me participate in } \\
\text { identifying a solution }\end{array}$ & 651 & -.469 \\
\hline I feel comfortable bringing problems to my supervisor's attention & .617 & -.522 \\
\hline Employees where I am employed do not work well together & & .354 \\
\hline $\begin{array}{l}\text { Fair Treatment } \\
\text { I feel that everybody is treated fairly and consistently at my workplace }\end{array}$ & 637 & -.507 \\
\hline $\begin{array}{l}\text { My supervisor is quick to point out what's wrong, but not so quick to point } \\
\text { out what's right with my performance }\end{array}$ & -.572 & \\
\hline $\begin{array}{l}\text { Listening Skills } \\
\text { My supervisor is a good listener }\end{array}$ & .626 & -.620 \\
\hline I feel that I can confront my supervisor about job related issues & .553 & -.513 \\
\hline $\begin{array}{l}\text { Sometimes I feel that my supervisor is being judgmental when he/she is } \\
\text { correcting me }\end{array}$ & -.492 & .574 \\
\hline
\end{tabular}


The data also indicate that employees also highly value empathy in their supervisors. Employees who received positive reinforcement by supervisors for jobs done well consistently perceived the supervisor as caring (.762), understanding (.753), patient (.721), respectful (.655), helpful (.587), and a good listener (.626). They also felt that they were treated fairly and consistently at work (.637). In addition, these employees felt comfortable in bringing problems to their supervisor's attention (.617), or confronting their supervisors about job-related issues (.553). They also appreciated their supervisors involving them in identifying solutions to those problems or issues (.651) and valued the supervisor's help (.587).

On the other hand, employees whose supervisors criticized them and responded to them negatively indicated just the opposite with statistically high levels of dissatisfaction in those areas of empathy: caring (-.576), understanding (-.709), patience (-.606), respectfulness (-.663), and helpfulness (-.481). In addition, employees rated the listening skills of their critical supervisors significantly lower (-.620); being judgmental (.574) than the skills of positive supervisors. They also perceived their critical or negative supervisors as uncaring, unconcerned, aloof, or indifferent (.678), and further, frequently felt ignored by their supervisors (.634). These employees were also more sensitive to what they perceived as verbal abuse from their supervisors (.568) and highly disliked their supervisors' venting their own frustration (.476), or worse, threatening termination as a motivator (.519). They did not feel that they were treated fairly and consistently at work (.507) and felt uncomfortable in bringing problems to their supervisor's attention (.522) or confronting their supervisors about job-related issues (.-513). They also felt that their supervisors did not involve them in identifying a solution for those problems or issues (-.469), nor did the supervisors offer to help with basic tasks (.-481).

\section{SUPERVISORY QUALITIES VALUED BY EMPLOYEES}

Our data indicated six, statistically significant areas of supportive and corrective confrontation that were valued by employees. They are ranked as follows, in terms of their relative importance: positive feedback for a job well done; empathy; respect; participatory management style; fair and equitable treatment of all employees; and listening skills.

\section{Positive feedback for a job well done}

The data indicate that employees highly value positive feedback from their employers when they are doing a good job. According to Williams (2005), the quality of any relationship largely depends on the quantity and quality of feedback received by the parties. Poor feedback often results in a poor relationship, while critical or abusive feedback results in critical or abusive relationship. Positive feedback, however, results in a positive relationship.

Our data indicate that, more than any other supervisory quality, employees desire and value positive feedback from their supervisors for doing a job well. In giving positive feedback, supervisors must avoid judgment and evaluation or advice; rather, they must describe a behavior or attitude the other person has the capacity to change or modify. In describing the behavior, supervisors must avoid abstract or conceptual terms which can quickly become sources of contention that distract from the real issues, in favor of concrete words to describe the problem and the solution. Supervisors can articulate desired behaviors, discussing what the employee can or should do, as opposed to giving the employee a list of "don'ts."

Karp (1987) recommends that supervisors use the following strategy when providing employees with supportive feedback:

1. Acknowledge the specific action and result to be reinforced.

2. Explain the effects of the accomplishment and state appreciation.

3. Help the subordinate to take full responsibility for the success.

4. $\quad$ Ask if the subordinate wants to talk about anything else.

5. Thank the subordinate for the good performance (pp. 243-244). 


\section{Empathy}

Supervisors who are lacking in social and emotional skill development are more likely to respond to employees in a negative manner; yet, the data indicate that employees highly value qualities most closely associated with empathy, such as caring, understanding, and patience. Supervisory confrontation requires competency in social, emotional, and nonverbal communication skills to be effective, especially when maintaining or building relationships. People respect others who hold them accountable for their behavior, especially when someone benevolently confronts them to help in learning and improving skills and to avoid harm.

In a positive sense, confrontations become opportunities for people to share their concerns with each other. For supervisors, identifying specific emotions and acknowledging the reason why someone is experiencing an emotional reaction is a critical component to listening with empathy (Sampson, 2003). Further, by correctly identifying their own emotions, supervisors are then able to manage those emotions and the emotions of others. For example, allowing employees to vent negative emotional energy without interruption or censure will enable an interpersonally skilled supervisor to remain calm and avoid making the confrontation personal (Sampson, 2003). The supervisor can better respond to what the person is saying, feeling and doing without provocation (Blakeman, 1977). Supervisors who maintain composure demonstrate self-confidence and strength, and inspire respect in employees.

\section{Respect}

The data also indicate that employees highly value supervisors who demonstrate respect toward them. When supervisors confront and correct in a constructive manner, employees understand and respect the effort to help them develop the behaviors and skills needed to perform their jobs effectively and efficiently. According to Karp (1987), corrective feedback and supportive feedback are essential to the employee's growth process, and "just as feedback must be specific and observable in order to be effective, it must be nonthreatening in order to be acceptable" (p. 239). A necessary prerequisite to corrective and supportive feedback, however, is accountability.

Accountability is in the employee's best interest, and employees respect supervisors who hold them accountable. When a supervisor makes an employee aware of inappropriate or unproductive behavior, respecting the dignity of the employee in demonstrating or describing alternative behavior can be effective and powerful in shaping new behavior. In supportive or corrective confrontation, being specific in describing the behavior is the most important rule in giving feedback to others (Karp, 1987).

Hoover and DiSilvestro (2005) recommend a systematic approach toward constructive confrontation that includes clear and well-articulated expectations along with follow-up and recognition in a timely manner. This approach reduces conflict and increases accountability. In addition, for accountability to be effective, the supervisor and employee must first outline the commitment (including expectations, methods, and performance measures). Next, employees must agree to confront each other, if necessary, to ensure maximum job performance. Finally, the guidelines for constructive confrontation must be the same for everyone--the only difference being the range of institutional responsibility (Hoover \& DiSilvestro, 2005).

Another way supervisors can demonstrate respect toward employees is by allowing the employees to save face and maintain dignity when they are wrong and do not want to admit the mistake. Rather than forcing the issue, a supervisor can allow the employee to make concessions without having to admit the mistake. As William Ury observes, superior power is useless "if it drives your opponent into a corner and makes him resist you with all his might. Leaving him a way out is a time-honored precept" (1991, p.105).

\section{Participatory management style}

Our survey findings also indicate that employees highly value a participatory management style, particularly when supervisors allow the employee to participate in problem-solving or when supervisors help the employee with basic tasks on the job. For the supervisor, successfully modeling appropriate behavior is essential in supporting (training) or correcting (retraining) employee performance. According to Sampson (2003), when the 
employee successfully uses the new behavior and receives favorable feedback, the employee is more inclined to replace the old undesirable behavior with the new desired behavior. When supportive and corrective feedback focus on specific behavior, it supports problem-solving, making it easier for the supervisor to control the interpersonal interaction.

Modeling behavior also reduces the negative consequences of supervisory delegation which, when taken to the extreme, is often met with employee resentment. Such resentment often leads to lack of respect and unwillingness to listen. In over-delegating, supervisors often place themselves in a superior position in relation to the employee. The ensuing distance between supervisor and employee leads to the supervisor's disconnection with the employee's job and the circumstances that inform it. In modeling behavior, supervisors both verbally and nonverbally communicate their engagement with and dedication to getting the job done. The job becomes something "we" must accomplish, rather than something "you" must accomplish.

\section{Fair treatment}

Employees value supervisors who treat them fairly. Fair treatment begins with setting expectations, following-up, and recognizing performance. On occasion, however, it is necessary and appropriate to apply discipline to change employee behavior. Failure to apply discipline creates a climate of permissiveness that can have overwhelmingly negative consequences for the organization (Williams, 2005). In applying discipline, supervisors and employees must avoid being harsh, because harshness destroys relationships.

Instead, supervisors can hold the employees respectfully accountable for their behavior by bringing the behavior to the employee's attention and explaining the problem face-to-face using nonverbal communication without intimidation. In addition, supervisors should refrain from calling employees inappropriate names or giving an opinion about the undesirable behavior. Ideally, the supervisor should discuss the incident objectively and describe his/her observations in concrete and behavioral terms. Karp (1987) recommends that supervisors employ the following steps in corrective feedback:

1. Immediately describe the event in behavioral terms and explain the effect.

2. Ask what happened.

3. Help the subordinate to take full responsibility for the actions.

4. Develop a plan to deal with the issues.

5. State confidence in the subordinate's ability (p. 244).

The goal of these steps is to educate or remind employees of the implications of their behavior with discipline administered (or acceptable behavior modeled) to change the behavior in a positive way.

\section{Listening skills}

A number of studies have indicated that good listeners make good supervisors (Penley, Alexander, Jernigan \& Henwood, 1991; Ramsey \& Sohi, 1997; Weitz, et al., 2008), so it should come as no surprise that employees are reluctant to share information with supervisors who have poor listening skills. As indicated in our survey results, many employees fear reprimand (.606) or termination (.519) as a result of simply attempting to share a problem with their supervisors (Tucker, 1993). The findings directly correlate to survey data indicate that employees highly value supervisors who engage in strong listening behaviors (.626). Listening skills are critical in providing supportive feedback, but as Williams (2005) points out, interpreting behavior and responding to others are not innate skills; they are skills that must be developed.

Skills associated with effective listening include: non-verbal cues, such as making eye-contact and minimizing environmental and physical distractions; chronemic considerations such as allotting enough time for the interaction; the ability to empathize with others; suspending judgment; and responding to feeling and meaning, including asking questions. 
In addition to employing non-verbal strategies during confrontation, supervisors should also begin and conclude counseling or grievance interviews with supportive feedback, and should address any corrective feedback in the middle of the meeting. This interview structure allows for a more positive reception of the corrective feedback by the employee. In addition, Karp (1987) recommends that supervisors never apologize about giving corrective feedback because apologies minimize the importance of feedback and discourage change. Supervisors should also avoid following any feedback with "but" to avoid the risk of negating prior supportive feedback (Karp, 1987).

Feedback supports growth by facilitating communication between both the supervisor and employee. The supervisor relates the situation in behavioral terms as he or she observes it, and the employee relates what was meant, felt, or thought as it relates to the situation (Karp, 1987). The purpose of feedback is to share what was seen and heard and how the behavior affected the situation, not to judge the other person. Therefore, supervisors must suspend judgment in order to listen actively to employees.

Only after the supervisor and employee have really listened to the other, can they avoid the more negative aspects of confrontation, ask the appropriate questions, and develop a plan to address or resolve the issues. According to Williams (2005), asking questions enables supervisors to direct the conversation without appearing overly controlling; further, the person asking the questions tends to control the conversation (Williams, 2005). Bargaining, compromising, reasoning and relying on knowledge and experience are all appropriate ways of resolving conflict.

\section{CONCLUSION}

Supervisors who are unskilled in confrontation negatively impact organizational culture, create unnecessary civil liability, affect productivity and employee performance. In addition, unskilled supervisors can cause conflict with employees and further, can undermine supervisor-employee relationships. Failure to confront can contribute to employee alienation and neglect, a primary issue in the workplace.

Understanding employee perception of confrontational behavior can not only improve supervisory leadership, but can also promote employee job satisfaction, motivate employees, eliminate the need for constant supervision, and influence the quality of and improve employee relationships. Supervisors can then focus on implementing and improving confrontational behaviors that have the potential of contributing the most positive outcome to the human resources of a company or organization: positive feedback for a job well done; empathy; respect; a participatory management style, fair and equitable treatment of all employees, and listening skills.

Employees place their personal and professional welfare in the hands of supervisors who (they hope) perform their jobs honestly and with integrity and benevolence. Effective interpersonal skills and a systematic approach within a set of guidelines can help supervisors provide supportive and corrective feedback in a consistent manner. Using a systematic approach can also help supervisors address interpersonal problems more effectively without damaging the supervisor-employee relationship. Beyond these relationships within a company, employees will treat customers the same way they are treated by supervisors. By paying attention to and improving the specific areas in confrontation that matter, supervisors can improve workplace relationships and the business relationships that sustain them.

\section{AUTHOR INFORMATION}

Tab W. Cooper earned his Bachelor of Science degree in Criminal Justice/Law Enforcement and Police Science and his MBA from Sam Houston State University. He has conducted post-graduate work, training, and research in the areas of management, business communication, communication studies, and counseling psychology. During his 20-year law enforcement career, he served as Captain with the University Police Department at SHSU and as a project coordinator with the Law Enforcement Management Institute of Texas (LEMIT). He helped develop and coordinate the Texas Police Chief Leadership Series (first mandatory police chief management and leadership training program in the United States), the Command Staff Leadership Series, and the state mandated New Chief Development Program. He also coordinated the 9-week command college for Texas peace officers. E-mail: twc001@shsu.edu 
Lucia Stretcher Sigmar, Ph.D., is Assistant Professor in the College of Business Administration, Sam Houston State University, Huntsville, Texas, USA. She teaches undergraduate courses in business communication and business and professional speaking, and is an officer of the Association for Business Communication, Southwest Region. E-mail: 1ss002@shsu.edu

\section{REFERENCES}

1. Bandura, A. (1986). Differential engagement of self-reactive influences in cognitive motivation. Organizational Behavior and Human Decision Processes, 38(1), 92-113.

2. Blakeman, J., Keeling, T., Pierce, R. \& Carkhuff, R. (1977). Interpersonal Communication Skills for Correctional Management. Amherst, MA: Human Resource Development Press, Inc.

3. Blanchard, K. \& Johnson, S. (1982). The One-Minute Manager. New York: Morrow.

4. Canary, D. J., Spitzberg, B., \& Semic, B. (1998). The experience and expression of anger in interpersonal settings. In P. A. Anderson and L. K. Guerrero (Eds.), Handbook of Communication and Emotion: Research, Theory, Applications, and Contexts (pp.189-213). San Diego, CA: Academic Press.

5. $\quad$ Carkhuff, R. (1983). Interpersonal Skills and Human Productivity. Amherst, MA: Human Resource Development Press.

6. Cormier, S. \& Hackney, H. (2005). Counseling Strategies and Interventions (6 ${ }^{\text {th }}$ ed.). Boston, MA: Pearson Education, Inc.

7. Karp, H. (1987). The lost art of feedback. The 1987 Annual: Developing Human Resources. San Diego, CA: University Associates, Inc.

8. Kornhauser, A. (1965). Mental Health of the Industrial Worker: A Detroit Study. New York: John Wiley.

9. Hatfield, E., Cacioppo, J., \& Rapson, R. (1994). Emotional Contagion. New York: Cambridge University Press.

10. Hoover, J. \& DiSilvestro, R. (2005). The Art of Constructive Confrontation. Hoboken, NJ: John Wiley \& Sons.

11. Kanungo, R. (1992). Alienation and empowerment: Some ethical imperatives in business. Journal of Business Ethics. 11, 413-422.

12. Lerner, J. S. \& Tiedens, L. Z. (2006). Portrait of the angry decision maker: How appraisal tendencies shape anger's influence on cognition. Journal of Behavioral Decision Making, 19, 115-137.

13. Newell, W., \& Stutman, R. (1989/90). Negotiating confrontation: The problematic nature of initiation and response. Research on Language and Social Interaction, 23, 139-162.

14. Penley, L., Alexander, E., Jernigan, I., \& Henwood, C. (1991). Communication abilities of managers: The relationship to performance. Journal of Management, 17, 57-76.

15. Ramsey, R.P. \& Sohi, R.S. (1997). Listening to your customers: The impact of perceived salesperson listening behavior on relationship outcomes. Journal of the Academy of Marketing Science 25(2), 127-137.

16. Sampson, S. (2003). Building Successful Workplace Relationships. Atlanta, Ga: SoTelligence, Inc.

17. Sashkin, M. (1984). Participative management is an ethical imperative. Organizational Dynamics, 12(4), 4-22.

18. Seeman, M. (1959). On the meaning of alienation. American Sociological Review. 24, 783-791.

19. Tucker, J. (1993). Everyday forms of employee resistance. Sociological Forum, 8(1), 25-45.

20. Ury, W. (1993). Getting to No: Negotiating with Difficult People. New York: Bantam.

21. Velasquez, M. (1982). The Right to Due Process in Business Ethics: Concepts and Cases. Englewood Cliffs, NJ: Prentice-Hall.

22. Weitz, B., Castleberry, C., \& Tanner, J. (2008). Selling: Building Partnerships ( $7^{\text {th }}$ ed.). Boston, MA: McGraw-Hill/Irwin.

23. Williams, R. (2005). Tell Me How I'm Doing. New York, NY: AMACOM Books.

24. Wolf, D. ( 1991). Killing the messenger. American Demographics, 13(7), 40-44.

25. Wubben, M., Cremer, D. \& Kijk, E. (2009). How emotion communication guides reciprocity: Establishing cooperation through disappointment and anger. Journal of Experimental Social Psychology, 45, 987-990. 


\section{APPENDIX A}

\section{Supervisory Confrontation Survey Questions}

1. My supervisor is a good listener.

2. My supervisor is understanding.

3. My supervisor is patient with employees.

4. My supervisor can be harsh with employees.

5. My supervisor cares about his/her employees.

6. My supervisor demonstrates respect toward employees most of the time.

7. My supervisor has high expectations from employees.

8. I feel that everybody is treated fairly and consistently at my workplace.

9. I feel that I can confront my supervisor about job related issues.

10. My supervisor is known to help employees with some basic tasks.

11. I feel comfortable bringing problems to my supervisor's attention.

12. My supervisor has been known to be verbally abusive to employees.

13. My supervisor is known to make impulsive decisions based on emotion.

14. When I make a mistake my supervisor should bring it to my attention.

15. When I do not follow policy or procedure my supervisor should remind me.

16. I want others to provide constructive advice or suggestions when I am not performing my job effectively.

17. I frequently volunteer information to assist my supervisor and other employees.

18. My supervisor encourage me when I feel like I am doing a very good job

19. My supervisor frequently threatens to fire employees to motivate them.

20. My supervisor frequently gives me positive feedback by telling me how I am performing my job correctly

21. My supervisor frequently scolds or talks down to me while providing me feedback about my work performance

22. My supervisor provides feedback immediately after the situation occurs

23. I feel that my supervisor ignores me.

24. My supervisor is frequently uncaring, unconcerned, aloof, or indifferent.

25. I dislike when my supervisor vents his/her frustration when confronting me about an issue at work.

26. My supervisor is quick to point out what's wrong, but not so quick to point out what's right with my performance

27. When my supervisor corrects me, I feel defensive or embarrassed.

28. When my supervisor corrects me, I want him/her to show me the effective or appropriate way to perform a task or behavior.

29. Sometimes I feel that my supervisor is being judgmental when he/she is correcting me.

30. I appreciate when my supervisor me what I did was the right way to perform a task.

31. Demonstrating how to perform tasks correctly helps me do my job better.

32. I normally change my behavior or the way I perform a task after receiving feedback from my supervisor.

33. When my supervisor describes to me how to best perform my job, I feel hassled and mistreated.

34. I prefer constructive feedback instead of disciplinary action for my behavior and performance at work.

35. When there is an issue involving me, my supervisor lets me participate in identifying a solution.

36. I would like for my supervisor to involve me in identifying a solution, particularly when I have to implement the solution. 
International Journal of Management \& Information Systems - Third Quarter $2012 \quad$ Volume 16, Number 3

NOTES 